\title{
Revolutionary State Formation and the Unitary Republic of Indonesia
}

Anthony Reid

Recent trends in Europe whereby established states have surrendered some powers toward a supranational Europe, on the one hand, and subnational regions on the other, make it possible to speak of a relaxation of the "sovereign equality" model that dominated the post-war world in which nation-states were presumed to be the sole and equal possessors of sovereignty. We should, however, be very careful about generalizing this globally. In particular, the new states of Asia have been in an intense period of nation-building since 1945 . The type of nationalism which Tønnesson and Antlov (1996) label "official," I prefer to call "state nationalism" to avoid Anderson's (I99I) negative use of the term, since it is the universal currency of states in seeking to create lovalty and homogeneity \{Reid 2009). This type is still extremely vigorous in Asia, where the task of turning "peasants into Chinese" (or Indians, Indonesians, etc.) is by no means complete. The acceptance by China in 1997 and Indonesia in 2005 of a certain degree of asymmetry in the position of Hong Kong and Aceh, respectively, may look like pragmatic retreats from the nationalist project, but there is still profound resistance in both these states toward recognizing the validity of self-governing "nations" within established states.'

It would be wrong to see this difference, however, as a consequence of either Asian cultural norms or long-term patterns of Asian statecraft.

On June 6,2007 , for example, the Chairman of China's National People's Congress, Wu Bangguo, seemed to undercut Asia's most impressive achievement of asymmerric pluralism in recent times, by telling the representatives of Hong Kong that "Hong Kong's administrative autonomy is not intrinsic... it is granted by the Central Government," Siraits Times, June 7, 2007 
Asia in general, and Southeast Asia in particular, has remained plural in its social organization, in contrast to the states of western Europe or the New World. Highland and small-island peoples remained unincorporated into states at all until the early twentieth century, and in many parts of Southeast Asia they are only becoming fully integrated in the current era of TV, mass education, and mobile phones. Before the twentieth century most Asian polities remained relatively resistant both to "Westphalian" norms of formal equality between sovereign nation-states and to the internal cultural homogeneity that accompanied this model. Many states continued to render tribute, or acknowledge asymmetry, in dealing with several international parties in different levels of deference (Reid \& Z Zheng 2009). Brantley Womack has made the point that "international relations theory, which remains rooted in the modern European experience of competitive nationalism," has much to gain from considering the older history of Asian ways of managing relations between polities (Womack 2006, p. 23).

This chapter will argue that the strong commitment of Indonesia after I9 45 (and by implication, of China and Vietnam) to a single homogeneous nation within former imperial borders is not an Asian but a post-revolutionary phenomenon. The states most uncompromisingly committed to radical political uniformity were those that entered the contemporary world through a political revolution that was committed to an ideal of a single, equal, and unqualified citizenship for all, without recognizing the legitimacy of older political legacies. The chapter will show with reference to the Indonesian case how the embracing of the revolutionary idea by the political elite in the middle decades of the century produced an uncompromisingly unitary model of state. The absence of historical roots for such a model, other than that of the reviled Dutch imperial system itself, served paradoxically to strengthen the persuasiveness of the uniform Indonesian identity - imagined but neutral. As pointed out in the introduction above, other (communist) revolutions emerging from lengthy guerrilla movements were more indebted to minorities that had supported them in opposition, and hence made concessions to "nationalities" as first adumbrated in the Soviet model. Nepal is an intriguing contemporary example. Yet in all such post-revolutionary regimes, political legitimacy is held to derive from the revolution itself, so that concessions to minorities are but means to a uniform end. Only to the extent that revolutionary legitimacy is eroded in the longer term and replaced by state nationalist rhetoric drawing again on history (the trend of postMao China), can other historic claims to identity make their comeback.
This chapter aims to establish the post-revolutionary model as an essential tool in the typology of twentieth-century state formation, in contrast to other options.

\section{DIFFERENT PATHS TO INDEPENDENT STATEHOOD}

The crucial watershed of the I940S and early I950s saw the birth or rebirth of most of Asia's states, which endured surprisingly effectively over the subsequent half century. Several of them achieved this state form through a revolutionary declaration in or around 1945 , which the world powers accepted reluctantly only after considerable bloodshed, from both external and internal challenges. I will take the Indonesian case as my prototype of this path, though China, Vietnam, Pol Pot's Cambodia (the extreme), and to some extent Burma, might be equally instructive.

By contrast, those new states born through an evolutionary path (particularly under British decolonizing auspices) accepted, in the interests of pragmatism, a diverse inheritance of asymmetric political forms. In particular, the extraordinary complexity of the Indian federal system, with its multiple political and language rights, is an understudied model for such formations, which this book helps to address. In Southeast Asia, post-war Malaysia provides a marked contrast with its fellowAustronesian- and Malay-speaking neighbor Indonesia, as is explained further below. Like Malaysia, the Philippines, the third major state with a diverse Austronesian population, achieved its post-war independence by peaceful evolution and negotiation. It had, however, also defined itself through revolution, like Indonesia, but a half century earlier in the uprising against Spain (1896) and the subsequent Malolos Republic. The commitment to a centralized state with equal sovereignty defined in this revolution began to fade only eighty years later, when the government made its first autonomy agreement with representatives of the Moro nation (Bangsa Moro) in 1976. This marks the beginning of the reconceptualizing of the Filipino state as multinational, with increasing discussion of a switch to federalism, balanced by continuing pressures to uphold the unitary ideal of the Malolos Republic. The vital question hanging over Indonesia's 2005 Memorandum of Understanding with the Aceh independence movement is how far Indonesia, too, can relax its definition of Indonesian national unity as the revolution that took place sixty years earlier loses its monopoly of legitimation.

In the centuries preceding the watershed of the I940s, the "Malay World" appeared extremely unlikely to be on a path leading toward strong, 
unitary states. It never developed bureaucratic, law-giving states of its own, and interior populations remained wary of the externally supported states on the coasts. Even the highly complex polities of pre-colonial Java and Bali seemed to have "an alternative conception of what politics was about" (Geertz I980, p. 135). A marked trend of modern scholarship on early modern Indonesia has been the quest to define the social and cultural glue that enabled these societies to develop great complexity in the absence of Weberian bureaucracy (Day 2002; Drakard r999).

The modern legal/bureaucratic state was introduced to the region by Dutch and British colonial regimes, which built their power, not by taking over pre-colonial states so much as by gradually building their own port-based regimes, first alongside, but eventually above more persona indigenous hierarchies. When in the twentieth century these colonial polities became effective states, they still maintained a facade of very diverse rajas, sultans, adathoofden, bupati, and chiefs, who served as sources of both legitimacy and mediation with the diverse populations for which they became responsible. Immigrant Chinese, Europeans, Indians, and Arabs provided the middle class for these colonial states but were not discouraged from continuing to think of their citizenship and "nationhood" as being elsewhere. Hence, the prevailing wisdom in both the Indies and British Malaya in the r 930 os was that independence was scarcely viable. B. C. de Jonge began his term as Governor-General in $193 \mathrm{I}$ with the statement that Holland had been in the Indies for 300 years and would be there for another 300 . Toynbee famously declared "When I touched at the Straits Setrlements on my way out East I realized that British Malaya was destined, by 'peaceful penetration,' to become a new Chinese province" (Toynbee 1931, p. 259).

Insofar as there were attempts to evade the nationalist pressure by devolving authority to more manageable units, feebly in the 1920 s and I930s but almost frenetically after 1945, complex structures of diversity seemed the only viable option. The map of Federal Indonesia constructed by the Dutch in $1946-1949$ as they sought an alternative to the Indonesian Republic was extraordinarily complex in its attempts to accommodate ethnic, linguistic, and political diversities (Reid 1974, pp. I06-I9; Schiller 1955).

The diverse local aristocracies being tutored in modernity by the Dutch may have found these federal structures appropriate, or even too radical. However, there were by the 193 os plenty of radical nationalists with little stake in traditional structures of any kind and a very low regard for them. In the early r 920 , Indonesia had the strongest communist party in Asia, riding a popular messianism about a golden future without oppression or inequality. The Dutch authorities arrested $x_{3}, 000$ alleged communists in $1926-1927$ and effectively eliminated the party from political participation for the rest of the colonial era. Revolutionary dreams, however, remained strong, especially outside Java where the colonial presence itself was new and relatively fragile.

What was the focus of longing for such radical nationalists? Lacking a name for their collective selves other than Indier (Indian), students from the Archipelago in Holland picked up the musty academic neologism "Indonesia" used in the title of a book by a German ethnographer (Bastian 1884 ). Ki Hadjar Dewantoro first used it for his Indonesian Press Bureau in 1913 , but from 1917 on the influential organization for the students from the Archipelago in the Netherlands called itself (in Dutch) the "Indonesian Union of Students." The idea spread quickly, borne by the aspiration that Indonesia's unity lay in its future, not in any particular past formation. It was a name entirely free of associations. When it acquired such associations in the $\mathrm{x} 92 \mathrm{z}$ s by frequent reiteration, they were again those of the future. In 1924 , the Indonesian communists founded the first political party to adopt this new term, calling their organization the Partai Komunis Indonesia, or PKI. The nationalist students in Holland called their journal "Indonesia Merdeka" (Free Indonesia) in 1925; in the same year, the international communist activist Tan Malaka published in exile his Toward the "Republic of Indonesia." In 1927, Sukarno established the Indonesian National Association (later Party - Partai Nasional Indonesia, or PNI), to fight for unity and independence, and popularized the slogan "Indonesia Merdeka," These associations tended to stick with the new term Indonesia - "free," "national," "republic" (Elson 2008).

In October 1928 , a meeting of regional youth movements, mainly supported by those studying in Dutch-medium high schools and universities in Java, decided to embrace the new idea in preference to established ethno-linguistic identities. In the subsequently farnous Youth Oath (Stumpah Pemuda) they declared, "We the youth of Indonesia acknowledge only one fatherland, Indonesia. We acknowledge only one nation [bangsa], Bangsa Indonesia. We uphold only one language, the Indonesian language." With this, the generation that would later drive the Indonesian revolution had already laid the basis for portraying an emphasis on their particular ethno-linguistic identities as anti-national. Although they largely spoke in Dutch, they were aided by the possibility of elevating the commercial and Islamic lingua franca of the Indies, Malay, to be the national "Indonesian language" of their aspiration. Only 2 percent of the 
Indonesian population was listed as Malay in the 1930 census, and this language threatened nobody, as Javanese 446 percent of the 1930 population) would have done.

Idealistic, educated Indonesian youth, therefore, already had a dream of independent modernity that was singular because it was detached from the divided present. The political nationalists among them, moreover, were inclined to dismiss the traditional aristocracy through whom the Dutch ruled, with all their culturally specific hierarchies, as an anachronistic and "feudal" facade, perpetuated by the colonial power to divide and rule. From their Dutch education, they absorbed an admiration for the modernity of democratic nation-states, and a distinct lack of respect for the decorative but largely impotent monarchs through whom the Dutch ruled. Despite the appearance of great political diversity in Netherlands India, they perceived the underlying reality of centralized colonial bureaucracy.

Sukarno was an ideal mouthpiece for the unitary "Indonesia" idea. From his emergence as a leader of nationalist forces after-the suppression of the PKI in 1926, he consistently championed the unity of all the sini (here) against the sana (there), in effect a racial unity that epitomized anti-imperial nationalism. He had phases of greater drawing on Marxist and Islamic sources, but he never wavered in proclaiming that the key to the "golden bridge" to a glittering independence lay through subordinating differences to the single great goal. In perhaps his most characteristic expression, the speech and pamphlet, "Achieving Independent Indonesia" (Mentiapai Indonesia Merdeka, I933), Sukarno drew on Marxist literature very selectively to demonize the West as a capitalist hell for the poor. Thereby, parliamentary democracy and individualism became the great evils to combat. Collective action under the guidance of a single vanguard party should galvanize the masses to uphold "socio-democracy" and "socio-nationalism" against the evils of individualism and capitalism (Sukarno 1933, pp. 66-7). Moreover, the party itself should have just enough Leninist theory (if not organization) to leave no intermediaries between the leadership and the masses, and give total control to its leader. "The democracy of the vanguard party is the democracy which foreigners call 'democratic centralism,' a democracy which gives the top leadership the authority to punish every deviation, to oppose ${ }^{2}$ any member or section of the party that endangers the struggle strategy of the masses" (Sukarno 1933 , p. 50). These ideas were only one strain among many in

The translation of Dahm (1969, p. i 55$)$ based on an earlier text, renders this as "expel," which may indicate some sanitizing in the 1970 s version I used. the Dutch period, but they became very central after 1942 and triumphed through a revolutionary process.

As a control counterexample, the British had established in Malaysia an admittedly less centralized colonial unit. Their domain in the "Malay World" was a patchwork of constitutional diversity. It included the Crown Colony of the Straits Settlements (Singapore, Melaka, and Penang), in which Chinese were a majority; the first four Malay monarchies on the Peninsula to be "protected" in the 1870 , which would later be welded into a common federal government in 1896 ; and five other "unfederated" sultanates jealous of their sovereignty as protectorates. It also comprised the "white raj" of Sarawak, which reluctantly surrendered sovereignty to the British in 1946; an autocratic sultan in Brunei; and a chartered company in North Borneo (Sabah). The conflict in the Peninsula between a robust Chinese nationalism (which was taking an increasingly communist path with Mao's rise), and a Malay ethno-nationalism seeking to retain sovereignty or at least dominance in Malay hands, dwarfed any dream of a unifying anti-British nationalism. Finally, Britain was in a position to reoccupy its territories quickly after the Japanese surrender, which the Netherlands was not, providing a much more promising revolutionary opportunity in the Indonesian case.

\section{THE MYTH OF UNITY IN THE REVOLUTIONARY I94OS}

The Japanese military administration (1942-1945) gave Sukarno the direct access to the masses that the Dutch had gone to great lengths to deny him - for which he remained very grateful to Japan (Sukarno I 966, pp. I $61-3,173)$. Though never wavering in his aim of Indonesian independence, Sukarno endorsed the Japanese wartime ideal of a do-or-die struggle against the West, with its corrupting evils of liberalism and individualism. Far more than others who cooperated for tactical, opportunist, or survival reasons, Sukarno passionately advocated the slogan of "Live or Die with Dai Nippon." To his increasingly skeptical fellow nationalists in the wake of Japanese defeats, he pleaded in October 1944: "Do all the comrades understand...that independence can be realized only by way o cooperation with Japan. I ask this here because I know that there are stil many among our people.... who are still intoxicated by liberalism, who make individualism an ideal, and do not want to participate in the war with its burden and bitterness" (cited in Dahm 1969, pp. 28 I-2).

The Japanese occupation resulted in other remarkable contributions to the revolutionary ideal of unity, despite Japan's own intentions to 
divide the Archipelago into different spheres of permanent Japanese rule. Firstly, they had absolutely no use for Dutch as lingua franca (in contrast to the preference of anglophone and francophone Japanese administrators in other colonies) and brutally forbade its public use, resolving the language question by promoting the use of Malay. Secondly, they further downgraded the status and autonomy of self-governing rulers and created a plethora of unitary organizations for all Muslims, all Christians, all women, and so forth. The greatest contribution to the unitary idea, however, was paradoxically, in their very different treatment of three regions. Java under the I 6 th Army was the only region for which Japan envisaged a token independence and where the military encouraged Javawide political movements and leadership. The Japanese 25 th Army initially saw oil-rich Sumatra as too valuable ever to let go, and only in March 1945 did it permit token Sumatra-wide representative bodies. In the Navy-ruled Borneo and the East, Japanese authorities did not allow any political activity because they envisaged these scattered and underpopulated islands as a permanent part of the empire.

Only Java-based delegates attended the principal opportunity to debate the shape of the future independent Indonesia, the Body for the Investigation of Indonesian Independence (Badan Penvelidik Kemerdekaan Indonesia, or BPKI) at the end of May r.945. Although a tenth of its sixtytwo members had been born outside Java, none lived there, and there was no voice for protecting the interests of distinct ethnic and regional interests. The only challenge to the nationalist dream came from Muslim delegates demanding some form of an Islamic state. Nationalists offered them a compromise in May but withdrew it in August after consideration of the non-Muslim regions' support. The BPKI, unsurprisingly, voted overwhelmingly for a unitary republic. A Christian Ambonese who was active in nationalist politics in Java, Johannes Latuharhary, found in the nineteen-man constitutional subcommittee only one supporter for his plea for a federal state. Only six delegates in the full body favored monarchy over a republic. Only Hatta and Mohammad Yamin, both Mingkabaus born in Sumatra, made vain pleas for building individual and regional rights into the constitution (Yamin 1959, pp. 230-9, 259, 299-300, 330-6). In the hothouse atmosphere of the late Japanese occupation, quasi-fascist ideals of unity, articulated in integralist form in a draft constitution by law professor Supomo, appeared untroubled by any practical diversity on the ground. Most of these same delegates believed their future unitary Indonesian state should extend to include Malaya, British Borneo, and Portuguese Timor (Reid 1974 , pp. I9-25).
Facing the growing certainty of an Allied return to eastern Indonesia, Borneo, and Sumatra, Tokyo subsequently overruled the desire of the local military authorities in these areas to keep them separate from the rapid independence preparations in Java. On the very day of the Japanese surrender, August I4, I945, three ill-prepared delegates from Sumatra and five from Borneo and the East arrived in Jakarta for what was expected to be the next step towards a Japanese-managed "independence" for Indonesia. Suddenly the theatre became reality. After independence was hastily proclaimed in a manner the Japanese could accept on August 17, the Japanese-sponsored Committee for the Preparation of Indonesian Independence (PPKI) was called upon to authorize the constitution, which had been prepared earlier in Java, and laid the basis for a new state in a hurried three-day meeting.

The delegates from outside Java were uniformly concerned about the Java-centered state that was likely to result, but they had little effect on a format that had already been determined without them. The most articulate of these delegates, Dr. Mohamad Amir from Medan, pleaded "that the maximum decentralization be allowed for the islands outside Java, that governments be set up there, and that the people there be given the right to manage their domestic affairs to the widest extent" (Yamin 1959 , pp. 4IO, 4I9). Far from allowing natural ethno-cultural units their own expression, however, the PPKI decided to establish only eight large provinces for the whole country - one each for Sumatra, Borneo, and Sulawesi and two for the smaller eastern islands. Except for the three in Java, each of the other five provinces was a mosaic of pluralism, with no dominant ethnicity or even religion (Reid I974, pp. I9-29). The governors appointed to these provinces had negligible power on the ground. Youth movements, some Japanese-trained, some Islamic, some communist, provided the real dynamic of revolution at the local level, and all were impatient with the compromises made by the established local elites. For these newly mobilized youth, Java and centralism represented the distant dream of a purer republic, not a threat to local autonomies in which they had little stake.

If the Japanese administration set the stage for the unitary charter of the Republic's beginnings, it was the revolutionary assertion of independence that provided real legitimacy and charismatic power. The established elites, with their local interests to protect, were on the defensive against the unitary dream throughout the revolution. They could not prevent the violent "social revolutions" of I945-I946 that swept away the kind of self-governing rulers the Malayan constitutions were 
designed to protect. Despite its ambivalence about these violent actions, the Republican leadership accepted their consequences as signaling the end of monarchy in Sumatra (Kahin 1985; Omar 1993; Reid 1979). In the I95OS, a uniform pattern of administrators (called bupati and camat on the Javanese model) appointed by the Interior Ministry in Jakarta eased out dozens of other monarchies in Borneo and eastern Indonesia through less violent means.

Aceh was the most critical test of the Republic's intentions for regional autonomy. Having fought determinedly against the Dutch conquest and endured its brief "colonial peace" only reluctantly, the Acehnese were known to be least likely to accept the restoration of pre-war conditions. Hundreds of recalcitrant Japanese soldiers and intelligence agents chose this place to continue their fight after August 1945. The question whether its resistance would be in the name of Aceh or Indonesia was quickly resolved in the six months following the Japanese surrender. This period saw the culmination of a struggle between provincial aristocrats (ulèëbalang) on whom the Dutch had relied to lead ro2 little "self-governments," and a popular Islamic movement (led by religious teachers, ulama), which had already sought the overthrow of the former at Japanese hands. After the Japanese surrender, the most aggressive of the ulëerbalang provocatively sought Dutch help to reestablish their pre-war position, whereas the youth wing of the ulama-led movement persuaded its leaders to embrace the revolutionary Indonesian Republic. On October I 5, 1945 , four prominent ulama, including Teungku Daud Beureu'eh, issued a declaration stating that "Every segment of the population has united in obedience, to stand behind the great leader Ir. Sukarno" because the antiDutch struggle of the Republic was a "holy war" like that which their ancestors had fought against Dutch conquest forty years earlier (Reid 2005, p. 346).

The ulama-led group prevailed in a brief civil war of December 1945 , and its leader Daud Beureu'eh became the dominant figure in the subsequent Republican government (Reid x979, pp. I8 5-217). Aceh remained the vital bastion of Republican strength after successive Dutch military actions retook all the key urban areas and economic assets elsewhere. Up until the victory of the Republic through the transfer of sovereignty a the end of 1949 , the local population accepted this ulama leadership as the local government with complete autonomy in practice. The conflict that emerged after 1950 was between the de facto autonomy of Aceh and many other localities that had made their own revolutions, and the unitary ideal proclaimed in I945. Because they had fought for the revolutionary ideal, the provincial leaders could not readily transform themselves into federalists or separatists once they experienced the realities of central control after 1950 . They claimed instead that the ideals of the revolution had been betrayed, and fought their battles with Jakarta on the basis of a different vision of the Republic as a whole.

In much of the rest of Indonesia, federal structures and a constitutionalism of checks and balances was developed from 1946 to 1949 , but these were fatally compromised because of their Dutch authorship as well as their internal weaknesses and pluralities. The revolution had disenfranchised the upholders of this system as traitors to the revolutionary idea, rather than as endangered minorities needing constitutional protection. The compromise under which the Netherlands and the world accepted Indonesian independence in I949 was in fact a federal Indonesia, uncomfortably merging the unitary Republic that held authority over most of Java and Sumatra with the elaborate federal structure the Dutch had built everywhere else. In Borneo they had patched together five weak federal states - two federations of rajas in the east, one "special region" in the west, and two "neo-lands" still too inchoate to have much sense of identity. In East Indonesia, the Dutch succeeded better in building an overarching federal state, the Negara Indonesia Timur (NIT), at a conference in Bali in December 1946. In the capital of this new state, Makassar, they constructed a fragile new edifice made up of a cabinet, parliament, and civil service. Internally, this structure rested on an extraordinary mosaic of local bodies. Some, representing pro-Dutch Christian areas like South Maluku (Ambon) and Minahasa, had indirectly elected representative councils; others were little more than confederations of traditional rulers, as in Bali and South Sulawesi. In Java and Sumatra too, the Dutch erected federal structures after they had reconquered, in July 1947 , the most productive plantation areas in East Sumatra and West Java and the oil-rich Palembang area of South Sumatra (Chauvel r990, pp. 233-57; Reid 1974, pp. 106-120).

Even though it was endorsed by the international community as an appropriate Dutch-Indonesian compromise, however, the federal constitutional structure collapsed completely within eight months of the transfer of sovereignty. Those who had feared the populist unitary thrust of the Republic found constitutional legality no protection against the "revolutionary political reality" on the ground (Feith 1962, p. 71). The Republican army, one of the forces most hostile to the Dutch-created structures, did not have to assert itself very strongly to bring about the dissolution of those states which had any military capacity of their own. 
The only serious armed resistance to the process came from Ambonese soldiers of the former colonial army who were now serving in the East Indonesian federal state. They provided the muscle behind the independence declaration of the Republic of the South Moluccas (RMS) in April 1950, after the Republic of Indonesia had sealed the fate of the federal NIT. For five months, they defended their capital in Ambon against a much larger Indonesian force and continued a guerrilla resistance in adjacent Ceram until r962 (Chauvel 1990, pp. 347-92).

At an ideological level, the symbolic power of the revolutionary ideal of unity contrasted strikingly with the factionalism of every local structure in the islands outside Java. The Dutch withdrawal magnified the problems they had faced in building any intermediate focus of loyalty between the local community or ethno-linguistic group and the bangsa Indonesia of revolutionary aspiration. The East Sumatran NST was built on three squabbling "indigenous" (asli) ethnic groups - Malay, Karo, and Simelungun - but could not ignore the even larger groups of Javanese and Toba Batak within it. Its attempts to raise another intermediate focus of loyalty to balance Java, notably through a Muktamar Sumatera (Sumatra Conference) bringing together sixteen regions in I949, served only to demonstrate how diverse and leaderless such a grouping would be (Omar 1993, pp. ( 52-4). In contrast, when Sukarno made his appeal for a single Indonesian focus in the multiethnic capital of the NST, Medan, it resonated precisely because it seemed to be in the realm of future aspiration, above politics: "We are one nation (natie), not three or four, but one bangsa Indonesia. There is no bangsa Kalimantan, there is no bangsa Minangkabau, there is no bangsa Java, Bali, Lombok, Sulawesi or any such. We are all bangsa Indonesia. There is no bangsa Sumatera Timur. We are part of a single bangsa with a single fate." ${ }^{3}$

\section{"RETURNING TO THE RAILS OF THE REVOLUTION"} UNDER SUKARNO

So marginalized and demoralized were Indonesia's ex-federalists in the I950s that the regional challenges of that period all came from the ranks of the revolutionary winners, who suppressed their ethno-nationalism under the cloak of rival visions of a unified republic. In 1949 , a Republican guerrilla movement in West Java refused to disarm and declared its cause to be the Islamic State of Indonesia (Negara Islam

'Propinsi Sumatera Utara, speech of January 23, 1950, pp. $386-7$.
Indonesia -NII) under S. M. Kartosuwirjo. In January I952, another disgruntled group of Makasar-Bugis guerrillas in South Sulawesi, under Kahar Muzakar, declared its support for this organization, even though its spirit was anything but national.

In I95 1 , feeling strong enough to return to a uniform system of administration throughout the Archipelago, Jakarta revoked the de facto selfgovernment that Aceh had established during the revolution. Sumatra had proved impossible to govern through the original single province, and Jakarta broke it into the three provinces that had already been decreed in 1948 , before the Dutch occupation of most of them. Aceh was amalgamated with a North Sumatra province with its capital in multiethnic Medan, and few Acehnese in its official leadership. There was no place in the new scheme for Daud Beureu'eh and many of his Islam-educated colleagues. In September 1953 , he led a rebellion, initially taking most of the Aceh war veterans with him. His grievances were regional, but he expressed them in theological terms, insisting that violence against the Dutch had only been justified by pursuit of an Islamic state. Hence, rebel Aceh, too, declared itself part of NII (Feith I962, pp. 54-55, 2I2-I 4; Sjamsuddin 1985 ; Sulaiman 2000, 2006).

Aceh's disaffection with centralism was deeper than most, and it continued to fester despite the appearance of a return to central control by 1957 . Jakarta restored Aceh's provincial status on January I, I957, but more importantly, the Indonesian military heightened its vigilance and its internal centralization. The army in the r950s was still largely territorial, and a mixture of bribe and coercion became necessary to integrate local veterans of revolutionary action under a unified command structure. The difficulties of this process stimulated the greatest of Indonesia's military challenges, the "colonel's revolt" of $1957^{-1958}$. This began in December 1956 , when the military commanders of both north Sumatra and central Sumatra declared martial law, suppressed communists and militant unionists in their regions, and broke their ties with the Jakarta government, insisting on the rights of their relatively wealthy regions to trade directly overseas. It was anti-communist disaffection among politicians in Jakarta, not any regional or federalist theory in itself, that provided the political leadership for this movement and a related one in North Sulawesi. The first national-level politician to join the colonels was leading economist Professor Sumitro, in May 1957. The leading politicians of the largest Islamic party, Masjumi, joined the movement in February 1958, and when their demands for a more moderate government were rejected, they declared an alternative one - the PRRI 
(Pemerintah Revolusioner Republik Indonesia) - led by former Prime Minister Sjafruddin Prawiranegara.

The overall effect of this polarization was to speed the demise of democracy and the ascendancy of the center over the provinces outside Java. The military and Sukarno, supported by communist and nationalist parties, acted swiftly to suppress the rebel forces militarily. They dispatched troops from Java and succeeded in taking major towns by July 1958 , resulting in the loss of several thousand lives. The troops from Java became a kind of occupation army for many years, while the representation of non-Javanese in the army officer corps dropped to below 40 percent. As in the defeat of federalism in 1950 , these events disqualified another generation of regional leaders from the political contest.

A drift toward authoritarianism, supported by both the military and the communist party but eloquently articulated by Sukarno, accompanied this suppression of regional revolts. Martial law had been in force since March 1957 , justifying the military's taking-over plantations and factories confiscated from their former Dutch owners and acting firmly against striking workers. Claiming a political stalemate on crucial issues such as the status of Islam in the state, Sukarno in 1959 abolished by decree the Constitutional Assembly, which was planning revisions to the federal constitution of 1950 . The country would "return" to the 1945 Constitution that placed very few constraints on a powerful president. A little-noticed supplementary decree allowed the right to operate only to the political parties that proved their national credentials by having branches throughout the country. Sukarno justified these steps in a notable Independence Day speech of 1959 , which he called, "Returning to the Rails of the Revolution":

Liberal democracy, which was born of the foam of the waves of that evil compromise [of 1950 ] and which dammed up and caused confusion in the Indonesian revolution, has now been blown clear away by the patriotic spirit and the fighting spirit of the People of Indonesia ...the course of the Indonesian Revolution... lost its way for a while, [but] finally found its way back to its own true rails. (Sukarno 1959, cired in Feith \& Castles I970, p. I09)

The shift to what Sukarno dubbed "Guided Democracy" in I959-1965 was a partial victory for one vision of what the revolutionary turmoil of the r940s had been about. It marked "the victory of those who had wanted a more fundamental restructuring of society on 'national' and 'revolutionary' lines, involving the destruction of virtually all centers of power outside the government itself" (Feith I967, p. 56). Yet the elements that supported this solution remained fundamentally divided, between the army, communists, and traditionalist Muslims. The establishment of Guided Democracy raised the rhetoric against the "enemies of the revolution" to a fevered pitch, only heightening the stakes between the contestants on the ground. The upshot of this period was, at the end of 1965 , a dramatic turn to the authoritarian right amidst an appalling trauma of violence, which inaugurated a new period of centralized authoritarianism.

In this radicalizing context the supporters of a more federal or plural construction of the state had to lie very low or flee. Chief among them was Mohammad Hatta - Sumatran, pragmatic, technically competent - who as vice president had been considered the necessary balance to the flamboyant and Javanese Sukarno. Hatta was also on record for favoring both federalism in principle (Sukarno I966, p. 195) and ending the obsession with revolution (Hatta 1954 , IV, p. I7 I). He resigned his position in 1956 and had no further influence. At the other political extreme, the rebels who had originally expressed their opposition in Indonesian terms now moved to federalism or independence. In September I955, the Acehnese rebels declared Aceh to be a federal state (negara bagian) of Indonesia, with Daud Beureu'eh as its head of state (wali negara). Hasan Tiro, who in $1945-1946$ had been a passionate young advocate of Aceh's struggle being one with Indonesia's, developed from his exile in New York a preferred format for a federal Indonesia (Tiro I958, pp. 98, I03-4, 150-3). When he returned to Aceh during a period of ceasefire and negotiations in r 959 , he could claim that the idea of a federal state was gaining ground among the other elements that had joined the PRRI uprising in 1958 (Feith \& Castles 1970, pp. 330-5; Sulaiman 2000, pp. 400-19). Only during Suharto's New Order did Tiro move to the idea of independence.

\section{SUHARTO'S AUTHORITARIAN CENTRALISM, I966-1998}

The triumph of Suharto and the Army amidst a reign of anti-communist terror in 1966 marked a dramatic turn away from Sukarno's leftist international stance and his catastrophic neglect of the economy. In terms of internal political control, however, the Suharto regime was able to implement the kind of authoritarian centralism about which Sukarno could only dream. Far from returning to the tentative pluralism of the I950s, which had provided for both a vigorous multiparty system supported by a free press and (in legal theory, at least) for Province and Kabupaten (district) executives chosen by their local elected assemblies, Suharto emphatically endorsed Sukarno's condemnation of this "Liberal" period. 
The Army, itself newly unified by the traumas of the 1960 , provided the muscle for him to impose what his political theorists called "monoloyalty," whereby all government officials were required to support the state party, Golkar, and many other centralized organizations established to deliver developmental goals. Mergers into two other parties and a prohibition from having any other basis than the state ideology Pancasila emasculated all political parties.

Law number 5 of 1974 revoked formally the autonomy legislation of the liberal $x 950$. In the new system, the center effectively chose governors, and decided on their budgets and guidelines. In 1979 , this central izing trend was carried down to the village level, replacing what had been extremely effective local institutions in places such as Bali and West Sumatra by a uniform system based on a simplification of practice in Java. Stiffened by a military element down to village level, the new village councils and the village-level women's and security bodies were chosen by "consensus," with the central bureaucracy having a large say (Malley т999).

The terror that inaugurated the New Order, the control of the media on issues such as national unity, and the militarization of the nationa myth as the basis for historical education at every level (McGregor 2007), made critical discussion of the ideology of "the unitary state of Indonesia" very difficult under Suharto. Instead, the most alienated elements began frankly planning for independence.

In New York, Hasan Tiro intensified his reading of Aceh history in the early 1970 . He grew increasingly excited by the independent role among the nations that Aceh had played up until I 873, in striking contrast to his youthful insistence during the revolution that "Aceh is an indivisible part of the Negara Republic Indonesia, so also its history too is one undivided part of Indonesian history" (Tiro 1948). In 1973, he claims to have "celebrated for the first time in many generations, in New York" the anniversary of the "glorious day" when Aceh defeated the first Dutch expedition sent to conquer it, in April 1873 (Tiro 1982, p. 62). At this stage, his mentor Daud Beureu'eh may have endorsed Tiro's call to pursue a path of independence.

The Indonesian invasion of East Timor in 1975 and the resistance to this new addition to the unitary Republic, both by sections of the international community and by the Timorese guerrilla movement, may have stiffened Tiro in this direction. In October 1976 he returned surrepti tiously to Aceh, and on December 4 he raised a "thousand-year-old flag" in a jungle clearing, where he read a lengthy declaration of Aceh independence based, essentially, on history. "Our fatherland, Acheh, Sumatra, had always been a free and sovereign state since the world begun [sic]. Holland was the first foreign power to attempt to colonize us when it declared war against the Sovereign State of Acheh on March 26, $1873 \ldots$...If Dutch colonialism was wrong, then Javanese colonialism which was squarely based on it cannot be right" (Reid 2004, pp. 305-8; Tiro 1982, pp. 15-17).

\section{REFORMASI AND THE NEW PLURALISM}

The fall of Suharto in May 1998 inaugurated a remarkable period of democratic reform (reformasi), including the freedom of a vigorous and plural press, the gradual removal of the military from the political process, and free and fair elections at the national and, eventually, regional levels. Aeronautical engineer B. J. Habibie, chosen to be vice presiden by Suharto in part because of his implausibility as a challenger for the presidency, nevertheless ascended to that office on Suharto's resignation. His most dramatic step was to resolve the East Timor running sore by allowing a referendum on independence, thereby offering new hope to separatists in Aceh and elsewhere. In a heady reaction against Suharto's heavy-handed bureaucratic centralism, the Parliament passed radical new autonomy laws in I999, which provided for elected local officials a generous sharing of revenues. The government permitted the first serious debate on federalism since 1950 (Bourchier \& Hadiz 2003, pp. 269-72; Mangunwijaya 1998 ).

In the liberal atmosphere of $1998-2001$, Jakarta's response to the clamor in Aceh for a referendum on independence was to attempt even more extensive autonomies than were being offered to other provinces and districts. An Aceh autonomy Law of July I 999 was stillborn because it looked to Acehnese like nothing more than the discredited and ineffective "special region" (Daerah Istimewa) deal that ended the I959 rebellion. A more consensual drafting effort under the Abdurrahman Wahid presidency Jed to the NAD Law of July 200I, so called because it renamed the Province Nanggroe Aceh Dartassalam (NAD), using the ambiguous Acehnese term nanggroe rather than Indonesian negara, long used for sovereign and federal states. Its concessions to Aceh - 70 percent of the oil and gas revenues for eight years and 50 percent thereafter - gained the support of Acehnese politicians working within the Indonesian structures, but did little to attract either the guerrillas of the independence movement (GAM) or the youth-based movement for a referendum (Miller 2006, pp. $30 \mathrm{r}-\mathrm{IO}$ ).

As had happened with the 1959 peace agreement, military intervention in the name of suppressing armed rebellion totally vitiated these 
autonomies. On May r9, 2003, President Megawati reestablished military rule in Aceh, bringing the level of military and police presence to between 45,000 and 60,000 strong, the highest it had been in Aceh's I30 years of intermittent military occupation (Schulze 2006, pp. 247-58, 262-4).

In light of this renewed quest for a military solution, the Helsinki agreement of August 15, 2005, which ended the war with a radical new proposal for Aceh self-government, was a striking turnaround for Jakarta. Two factors had made it possible. First, the election of the Indonesian President, Susilo Bambang Yudhoyono (SBY) and second, the massive earthquake and tsunami that devastated coastal Aceh, including its capital, on December 26, 2004. Suddenly, international attention was focused on Indonesia's response to the crisis, and the continuation of violence no longer seemed acceptable to anyone. The Helsinki-based Crisis Management Initiative brokered a Memorandum of Understanding between GAM and the Indonesian Government. It proposed the deployment of an international Aceh Monitoring Mission led by appointees of the European Union but also comprising delegates of the Association of Southeast Asian Nations (ASEAN).

If we exclude the decision to let go East Timor, this peace agreement is the most significant sign so far that the unitary dynamic of postrevolutionary nationalism is weakening. It granted to Aceh "authority within all sectors of public affairs," excluding "foreign affairs, external defense, national security, monetary and fiscal matters, justice and freedom of religion." National laws and international agreements "of special interest to Aceh" would only be agreed after consultation with the Aceh legislature. Aceh would have its own flag, crest, and hymn, and a ceremonial head of state called a wali nanggroe, the term that GAM had applied to Hasan Tiro. Aceh could raise its own external loans and international investments, administer its ports and airports, and enjoy 70 percent of the revenues from oil and gas "and other natural resources," in perpetuity. In return for GAM's acceptance of Aceh's place within Indonesia, the center would permit its fighters to play their part in the regional election of officials that was agreed for April 2006, though eventually held only the following December. This agreement waived Sukarno's rule that only nationally organized political parties could contest elections in Indonesia and gave GAM activists the opportunity to campaign as independents and to create or support an Aceh-specific party. ${ }^{4}$

The full text is available at http://www.cmi.fifiles/Aceh_MoU.pdf [Accessed March 3 , 2009 .
A greater test as to wherher the post-revolutionary period had passed was the need to get through the Indonesian Parliament a "Law on Governing Aceh" that would embody these concessions in Indonesian law, replacing the $200 \mathrm{I}$ NAD law. Just as in the former Soviet Union, the favorable window of opportunity making it possible for democratization to translate into self-determination for disgruntled minorities had lasted only for about three years after x 998. Nationalist rhetoric quickly reestablished itself among elected members of Parliament, making many of them more resistant to asymmetric concessions than the government itself. Centralist sentiments were equally strong in the Ministry of Home Affairs, which produced a draft for Parliament sharply different from both the Helsinki agreement and the draft proposed by legislators and officials in Aceh itself. When Parliament did enact the much-debated law four months behind schedule, in July 2006 , it provoked a one-day strike in Aceh and much criticism from international stakeholders in the peace process. It was even harsher in spirit than in practice, reasserting Jakarta's overarching sovereignty by inserting central government oversight into virtually all areas. 5

The changes on the ground, nevertheless, are already a significant departure from Indonesia's unitarist traditions. These changes brought GAM into mainstream politics, allowing one of its intellectuals, Irwandi Yusuf, to take office as an elected Governor in February 2007 through an electoral process that was unique to Aceh. The Aceh concessions have inaugurated a first step toward asymmetric government after sixty years in which the momentum was entirely in the other direction, toward imposing legal and bureaucratic uniformity on an exceptionally diverse society. The concessions support Michael Keating's argument that accepting differential claims on the state can be the strategy that is most compatible with justice and democracy when communities have very different histories and memories (Keating 2001, pp. viii, 102-33). A distinctive memory by Acehnese of both Aceh's own pre-colonial sultanate and its unusual relationship to the state nationalism of Jakarta requires some acknowledgment of Aceh's difference. If it turns out that an anomalous or asymmetric status is the only way to keep Aceh within Indonesia peacefully, Indonesia will have discovered through a bitter and painful route a formula that Malaysia had had thrust upon it at birth. See Taufiqurrahman (2006) "Aceh Bill Passed Despite Opposition," Jakarta Post, July
18, 2006, and International Crisis Group (2006) "Aceh: Now for the Hard Part", Asia

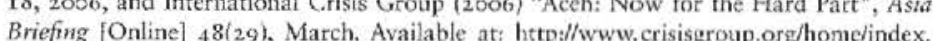
cfm?id=4049 [Accessed April 6, 2009]. 
MALAYSIA'S ASYMMETRY AS CONTRASTING CASE

In complete contrast with Indonesia's path to independence, in Malaysia the communists, the only group with the arms and ideology to move, did not seize the revolutionary opportunity presented by the Japanese surrender. The British Commonwealth forces, in alliance with the conservative Malay establishment, subsequently defeated and marginalized the Malayan Communist Party. While its cadres in principle shared with Indonesian revolutionaries a view of undivided and equal sovereignty, leaving no place for historic or ethnic particularities, they were too culturally Chinese and oriented to the PRC leadership to appeal effectively to other ethnic groups. What prevailed was therefore a pragmatic British style of compromise and constitutional complexity, stitching together radically dissimilar constitutional entities as well as ethnically very diverse populations.

The defining moment of Malay nationalism occurred in the same frenzied period when Indonesians were overthrowing their traditional rulers, but led in the opposite direction. The party that channeled Malay nationalism for the subsequent sixty years, UMNO, emerged from the struggle to reject Britain's moves to transfer sovereignty from the nine sultans to a nation-state-like Malayan Union in 1946. While young Indonesians were motivated by "the sovereignty of the people" (kedaulatan rakyat), young Malayan Malays campaigned for "sovereignty for His Majesty" (daulat Tuanku) (Omar I993). The British were compelled in effect to erect even more complicated federal arrangements than they had anticipated, making allowance for the maximum continuity between nine separate Malay sovereignties and the new state. Recent studies have confirmed the dominant hand of Britain in designing the architecture of independence (1957) as well as the formation of a broader Malaysia that included Singapore, Sarawak, and Sabah (1963) (Fernando 2002; Harper I999; Tan 2008). For all this, one can argue that the elaborate series of deals and compromises that made Malaysia possible reflected political reality rather better than the heroic ideal of national unity and solidarity did in Indonesia.

Without a revolution, federalism was the only possibility to emerge from this situation. By detaching Chinese-majority Singapore and suppressing a Chinese-dominated communist insurgency, the British had stitched together a Federation of Malaya in 1948 that became independent in 1957 . It linked the nine Malay monarchies, each jealous of jts sovereignty, with the two cosmopolitan settlements of Melaka and Penang under appointed governors. The headship of state, rotating among the nine sultans, retained British-era rights over religious affairs and land, while elected state and federal governments took over from the British the business of running the booming economies and multination societies. The federation became still more asymmetric with the formation of Malaysia in 1963 . The problem of pro-China sentiment in Singapore was resolved by bundling it into the federation with fewer elected representatives than its population warranted. By giving more seats than their populations merited to the new Borneo states of Sarawak and Sabah, the government also intended to balance the Chinese majority. Brunei's autocratic Sultan Omar Ali Saifuddin proved unwilling to accept a position equivalent to one of the Malayan sultans and eventually went his own way to independence. Singapore enjoyed autonomies in financial and legal arrangements, and Sarawak and Sabah in internal migration into their states. There were reassuring guarantees (overridden in time) about maintaining the place of English and resisting the hegemony of Islam in the newly joining states.

These makeshift arrangements are not universally accepted as a success (Case 2007). Singapore's departure after only two years in the federation demonstrated its internal tensions and left Kuala Lumpur and the Malay-dominated federal government more dominant over the states than had been envisaged. Yet, in contrast to East Timor's entry and exit from Indonesia, Singapore's story seems a triumph of pragmatism and peacefulness. In addition to different states having different rights, Malaysia's asymmetry extends to a multiethnic form, whereby "Malays, Chinese, and Indians" (often forgetting the numerous minorities, especially in Sarawak and Sabah) are accepted as separate ethnic groups with different claims on the state. In East Malaysia, diverse indigenous peoples have better claims to indigeneity than most Malays but lack the political leverage to draw similar benefits for themselves. They nevertheless succeeded, in 1995, in having two of their languages, Iban in Sarawak and Kadazandusun in Sabah, accepted into the state curriculum in their respective states (Reid 1997), succeeding where far stronger ethnic groups in Indonesia failed.

In marked contrast to post-revolutionary Indonesia, which heroically asserted the sovereignty and equality of all its people, Malaya/Malaysia emerged as a typically British muddle of inconsistencies and compromises. The Malaysian state appears permanently flawed by its inability to treat its citizens equally, even in law, and still less in political rhetoric These inconsistencies came about through the pragmatic compromises, often British-inspired, deemed necessary to bring different groups into 
the state (if not altogether the nation). By comparison with the revolutionary assertions of principle in Indonesia, they look messy and morally indefensible, yet they have on the whole kept the peace and made possible both an economic growth and a stable democracy that are the envy of Malaysia's neighbors.

\section{CONCLUSION}

Indonesia's post-revolutionary unitarism, like that of France and China, has achieved remarkable success in turning "peasants into Indonesians," and liberating its people from entrenched differences of class, race, and descent. In the very long term, this should prove to be a source of great strength for the nation-state. This spectacular achievement, however, has come at a very high cost over the first sixty years. The issues that can be readily measured, such as the toll of violence (horrendous in Indonesia, especially in 1965-1966 and 1996-2005 - Anderson 2001; Coppel 2004) and economic performance, suggest that Malaysian asymmetry has been far more successful than Indonesia's unitary state (Reid 2007, pp. $157-62)$. The overriding of legality involved in the revolutionary path also had incalculable costs for Indonesia's legal system, while the need for affluent minorities to buy protection rather than rely on legal and constitutional guarantees has helped corrode the military and bureaucracy with corruption.

Given the extreme heterogeneity of the Archipelago and its historic resistance to bureaucratic states of any kind, it may be that the quasimystical space that a unitary Indonesian Republic sought to fill in its people's imagining was the only way it could perform the miracle of nation building. Yet there were also clear dangers in this path, indicated by the steadily greater role the military came to play in state affairs between I 945 and 1980 and its frequent resort to force to suppress dissent. While Indonesia's course looked more promising than Malaysia's in the 19505 , the reverse has been the case at most periods since. However, the remarkably democratic outcome of the 1998 reformasi, including the readiness to attempt new solutions in East Timor and Aceh and the legislation for regional autonomy in general, may mean that the balance sheet is about to turn again, and Indonesia may prove able to experiment more effectively from its unitary foundation than can Malaysia from its entrenched asymmetries. 